\title{
Variability and Sources of Output Growth in Major Oilseeds of Rajasthan
}

\author{
Kailash Chand Bairwa ${ }^{1}$, Harkesh Kumar Balai², G.L. Meena ${ }^{2}$, Anju Yadav ${ }^{2}$ and \\ Dasharath Prasad ${ }^{3}$
}

${ }^{1}$ Department of Agricultural Economics, College of Agriculture, Agriculture University, Jodhpur, Rajasthan India ${ }^{2}$ Department of Agricultural Economics \& Management, Rajasthan College of Agriculture, MPUAT, Udaipur, Rajasthan, India ${ }^{3}$ Department of Agronomy, Agricultural Research Station, Sriganganagar, SKRAU, Bikaner, Rajasthan, India

*Corresponding author: kailashiari@gmail.com (ORCID ID: 0000-0002-4278-3109)

Received: $15-01-2021$

Revised: 23-02-2021

Accepted: 27-02-2021

\begin{abstract}
Rajasthan state is the second largest oilseeds producer and land coverage in the country. The share of oilseed crops is scheduled the significant growth in area and output in latest 20 years. Nevertheless, compare to wheat and gram, the growth rate of area and production of several oilseeds is less significant and there exist wide instability in their productivity in scattered part of the state. This study investigates to growth, its contributors and variability in area, production and productivity of major oilseed crops. The study period from 1990-91 to 2019-20 was divided into three sub-periods viz., period-I (1990-91 to 2004-05); period-II (2005-06 to 2019-20) and Overall study Period (1990-91 to 2019-20). Time series data were collected from various public E-sources to compute the growth, instability and decomposition in oilseeds production. It was revealed from the analysis that growth of kharif oilseeds was higher than rabi oilseeds. The highest instability (31.78) in production and productivity was reported in period-I for kharif oilseeds. In case of relative contribution, the area effect (416.85) and yield effects (211.10) were more effective in production of taramira and sesame crops, respectively. This analysis suggested that during period -I and II area effect was dominant in changing output of taramira and rapeseed-mustard.

\section{Highlights}

(0 Highest instability was reported in production and yield of kharif oilseeds.

0 Area and yield components were contributed more in taramira and sesame oilseeds.
\end{abstract}

Keywords: Growth rate, Decomposition analysis, Kharif oilseeds, Rabi oilseeds and Instability

Agricultural production in Rajasthan is predominantly rainfed with the net area sown during 2017-18 was 179.03 lakh hectares which reported 52.22 per cent of total reported area (DES, 2020). Assortment in weather and climatic conditions of the state is acceptable for growing of various foodgrain and oilseed crops. Rajasthan state is major contributor in oilseeds production of India. Among nine oilseed crops, sesame, rapeseedmustard, taramira, groundnut, castor and soybean are produced at large scale in the state. Soybean, sesame, castor and groundnut cultivates in rainy (or Kharif) season, while taramira and rapeseedmustard are suitable for winter (or Rabi) season. The Rajasthan state held second upmost position in area and production of oilseeds in the country. Apart from these, state has prime position in production

How to cite this article: Bairwa, K.C., Balai, H.K., Meena, G.L., Yadav, A. and Prasad, D. (2021). Variability and Sources of Output Growth in Major Oilseeds of Rajasthan. Economic Affairs, 66(1): 71-77.

Source of Support: None; Conflict of Interest: None (c) $\rightarrow$ 
of rapeseed-mustard followed by sesame and soybean. Agricultural sector plays a significant role in state's economy. Even though, its share in state gross domestic product (SGDP) has declined from 28.56 per cent in 2011-12 to 24.42 per cent in 2018-19 at constant price 2011-12 (DES, 2019). In Rajasthan, the contribution of oilseeds in total agriculture area and production is about 21 and 34 per cent respectively. These crops contribute a major part to agricultural gross domestic product (GDP). Technology Mission on Oilseeds programme was implemented by the government in 1986 to expand the oilseeds production and achieve the 18 million tone target of $7^{\text {th }}$ five year plan.

We are well known about the five essential components viz., carbohydrates, fats \& oils, minerals, protein and vitamins of human diet. In balanced diet, the per capita per day requirement of oils \& fats for a vegetarian and average dietary human is 35 gram and 38 gram respectively (Shukl et al., 1982). The oilseeds are only source of fats and oil for vegetarian people. The edible oilseed grains are used not only in production of cooking oil and food products but also in non-consumable purposes of medicine, cosmetics and industry. Away from these, processing industries of this sector is also helpful in providing employments opportunity in terms of skilled and unskilled labour.

Rajasthan state has significant advances in food grain crops viz., wheat, pearl millet and maize and obtained self-sufficiency to them. However, performance in other crops especially in oilseeds is not so good therefore; the government is concentrating on these crops. The return to investment on oilseed farming is still holding high risk due to uncertain conditions on rainfall, temperature, humidity, etc. The traditional varieties have not been successes to bring desired changes in their production. In spite of these, there are lot of limitations on technological head such as insufficient supply of good quality seeds, hesitation to accept high yielding hybrid varieties, unable to purchase the fertilizers and pesticides due lack of strong financial supports etc. Thus, there are various kinds of constraints to stagnant the yield of these oilseeds.

The oilseed sector is quit composite with the involvement of many market functionaries like farmers, processing firms, middlemen and consumers throughout the supply value-chain of oilseeds. The government is also involved in oilseeds supply value chain to protect the prime welfare of different stakeholders. The building up scenario of oilseeds is blow with speedy alteration within an assortment of technologies, market interventions, policies and trade situations. A logical investigation of these issues will be helpful in formulating suitable operational and strategic policies to obtain the predetermined targets along with self-sufficiency in edible oil and oilseed production.

Based on economic importance and continuously expanding gap between supply and demand of oilseed grains and their products, it will be most important to study the growth, instability and factors contribution in the progress of this sector. The present study is based on following recognised objectives: 1) to appraise the temporal and regional trend patterns in area, production and yield of major oilseed crops in Rajasthan; 2) to examine the variability in area, production and yield of major oilseeds, 3) to estimate the contribution of acreage and productivity in production performance of selected oilseeds and suggestive policy implication.

\section{MATERIALS AND METHODS}

The contemporary investigation is principally based on groundnut, soybean, rapeseed-mustard, castor and sesame oilseeds which have contributed more than 90 per cent in area and production of total oilseed crops in the state (T.E. 2017-19). The required secular time series data on area, production and productivity of selected oilseeds crops are collected from various digital records compiled and issued by Directorate of Economics and Statistics, Government of Rajasthan. Oilseed production is an integral part of crops farming system of the country with the acreage of 25.50 million hectares and production of 32.26 million tones (2018-19). About 23 per cent area and production of oilseeds is contributed by Rajasthan state. Therefore, this state is selected to find out the consequences on pre-determined objectives. The study period of 30 years from 199091 to 2019-20 is selected for this analysis. Further, the selected study period is divided into three sub-periods' viz., period-I (1990-91 to 2004-05) and period-II (2005-06 to 2019-20) and Overall study Period (1990-91 to 2019-20). 
Compound Annual Growth Rate (CAGR): During past studies, many scientists and scholars were used various form of function to estimate the growth rate in production, export and wholesale prices of agriculture, horticulture, animal production, fisheries products at national as well as state levels (Basitine and Palanisami, 1994; Joshi and Saxena, 2002; Srivastav et al. 2010; Agarwal et al. 2011; Kumar et al. 2018;). However, no one presented latest detailed appraisal study on oilseeds sector in Rajasthan context. Some of the important functional forms tried were linear, exponential, quadratic and power function. However, it was found that the exponential function $Y_{t}=a b^{t}$ is better and extensively used. In the recent investigation, compound annual growth rate in area, production and yield of selected oilseeds in the state is calculated by using the exponential growth function form (Angles, 2001) as given below:

$$
Y_{t}=a b^{t} U_{t}
$$

Where;

$Y_{t}$ is dependent variable (area, production, yield or farm harvest price) quantity/value in year " $t$ " of each oilseed crop; $a$ is intercept; $b$ is regression coefficient; $t$ is time in years as $1,2,3,4 \ldots \ldots \ldots . . n$ and $U_{t}$ is error term in year " $t$ "

Now, Equation (i) is converted into log form to make it convenient and written as:

$$
\log Y_{t}=\log a+t \log b+\log U_{t}
$$

Equation (ii) is computed by using Ordinary Least Square Method.

The compound annual growth rate $(G)$ is calculated by the equation as given below:

$$
G=\{(\text { Antilog of ' } b ')-1\} \times 100
$$

\section{Instability index}

Instability index can be measured by coefficient of variance, index of dynamic instability and CuddyDella Valle instability index. Out of these, CuddyDella Valle index de-trends to time series data and shows the precise track of the variability. Therefore, this method is selected to measure the instability in area, production and productivity of oilseeds
(Nimbrayan et al. 2019). The Cuddy-Della Valle instability index is worked out as:

$$
I=C V \times \sqrt{\left(1-R^{2}\right)}
$$

Where; $I$ is the instability index (\%), $C V=$ Coefficient of Variation (\%), and $R^{2}$ is the Coefficient of Determination from a time trend regression adjusted by the number of degrees of freedom.

Decomposition analysis: Minhas and Vaidyanathan (1965), was used decomposition analysis model to measure the relative contribution of acreage and yield to change in total production for major crops. Further, Sharma (1977) redeveloped to this model and several scientist and researchers (Kalmkar et al. 2002) were used this model to worked out contribution of acreage, yield and their interaction in the growth of output of crops in different states. The total change in production of oilseeds can be de-composed in three components viz., yield, area and interaction effects. The formula used in decomposition is explained as follow:

$$
Q_{i}=A_{i} Y_{i}
$$

Where,

$Q_{i}=$ Production of $i^{\text {th }}$ oilseed crop in India; $A_{i}=$ Area of $i^{\text {th }}$ oilseed crop; $Y_{i}=$ Productivity of $i^{\text {th }}$ oilseed crop; $i=1,2,3$ and 4

$$
\begin{aligned}
& \text { Now, } Q_{0}=A_{0} Y_{0} \text { and } \\
& Q_{1}=A_{1} Y_{1}
\end{aligned}
$$

Where; $A_{0}, Q_{0}$ and $Y_{0}$ stand for area, production and productivity of oilseed crop in base year and $A_{1}, Q_{1}$ and $Y_{1}$ stand for area, production and productivity of same crop in current year.

$$
\begin{aligned}
& \left(Y_{1}-Y_{0}\right)=\Delta Y_{1} \\
& \left(Q_{1}-Q_{0}\right)=\Delta Q_{1}
\end{aligned}
$$$$
\text { Further, }\left(A_{1}-A_{0}\right)=\Delta A_{1}
$$

Now substituting the terms represented in equation number (vi) into equation number (vi)

$$
\begin{aligned}
& Q_{1}=\left(A_{0}+\Delta A_{1}\right)\left(Y_{0}+\Delta Y_{1}\right) \\
& \Delta Q_{1}=\left(Q_{1}-Q_{0}\right)=\left\{\left(A_{0}+\Delta A_{1}\right)\left(Y_{0}+\Delta Y_{1}\right)\right\}-A_{0} Y_{0}
\end{aligned}
$$


or

$$
\begin{aligned}
& \Delta Q_{1}=\left(Y_{0} \Delta A_{1}\right)+\left(A_{0} \Delta Y_{1}\right)++\left(\Delta A_{1} \Delta Y_{1}\right) \\
& \text { Area effect }+ \text { Yield effect }+ \text { Interaction effect }
\end{aligned}
$$

The expression on the left hand side (LHS) of equation (v) decomposes the period wise change in production and on the right hand side (RHS) represented three components of de-composition viz., area effect, yield effect and interaction effect of area and productivity.

\section{RESULTS AND DISCUSSION}

Growth rate analysis: The season wise growth performance of area, output and yield of oilseed crops were calculated for different three periods is presented in table-1. During period-I, the highest growth rate in area, output and yield was reported in kharif oilseeds. The production and yield of kharif season oilseeds was grown significantly at 5.1 per cent per annum. At the same time area under kharif season crops was grown non-significantly at 1.1 per cent per annum. During period-II, Similar pattern of growth was also reported in kharif season oilseeds where the output and yield was increased at 4.5 per cent and area at 2.7 per cent annually. The area, output and yield of kharif oilseeds were grown significantly at 3.2, 6.1 and 6.1 per cent respectively in the period-III. It was concluded from the results that performance of kharif season oilseeds was far better than rabi and total oilseeds crops in all three periods. The change in level of output was mainly contributed by higher yielding varieties. At national level, similar pattern of growth in area, production and productivity of major oilseeds was reported by Reddy and Immanuelraj (2017).

The growth rate of area, output and yield of oilseed crops is showed for all three periods viz., period-I (1990-91 to 2004-05) and period-II (2005-06 to 201920) and Overall study Period (1990-91 to 2019-20) were presented in table 2. During 1990-91 to 2004-05, the growth rate in area and output of castor was 12.9 and 13.7 per cent followed by soybean, groundnut, sesame and others oilseeds. The technological factor viz., development of new varieties and production practices were major source of output growth in this period. Among these major oilseed crops, the output of groundnut was expanded at 10.3 per cent per annum followed by castor. During period-II, the highest growth rate in area, output and yield were reported in groundnut followed by soybean and castor crops. At the same time, apart from major oilseeds, area and production of remaining oilseed crops were also grown in two digits. The output of castor was boosted up at 12.1 per cent followed by groundnut and soybean at 7.4 and 5.3 per cent annually during overall study period. In recent past period, attractive minimum support price for oilseeds is coerced to expand the area under these crops. Bairwa, et al. (2020) in their study reported that area and production of cumin in Rajasthan was augmented at 4.5 and 3.87 per cent per annum during 1991-92 to 2004-05 period.

Instability in acreage, output and yield major oilseeds: the variability in area, output and yield of kharif, rabi and total oilseeds were computed and reported in table 3 . It was concluded from the table

Table 1: Season wise compound annual growth rate in area, production and yield of oilseed crops in Rajasthan

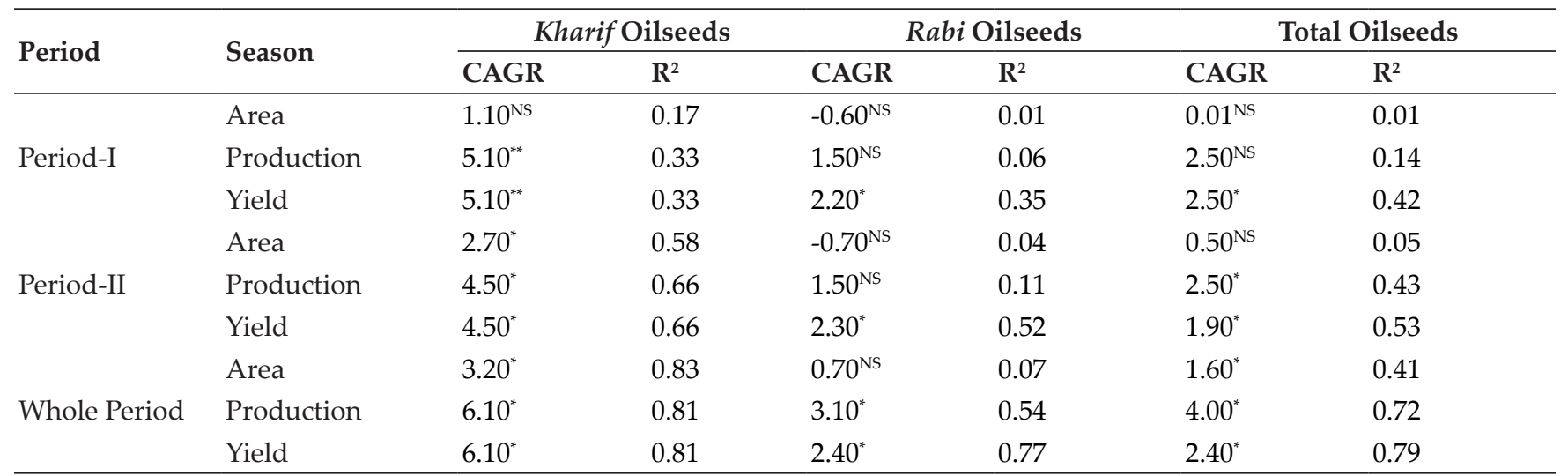

Note: "Significant @ 1\%, ${ }^{* *}$ Significant @5\% and ${ }^{\text {NS}}$ Non-significant; Source: Authors own computation. 
Table 2: Crop wise and period wise compound annual growth rate in area, production and yield of selected oilseed crops in Rajasthan

\begin{tabular}{|c|c|c|c|c|c|c|c|c|c|c|}
\hline \multirow[t]{2}{*}{ Crops } & \multirow[t]{2}{*}{ Parameters } & \multicolumn{3}{|c|}{$\begin{array}{c}\text { Period-I } \\
(1990-91 \text { to } 2004-05)\end{array}$} & \multicolumn{3}{|c|}{$\begin{array}{c}\text { Period-II } \\
\text { (2005-06 to 2019-20) }\end{array}$} & \multicolumn{3}{|c|}{$\begin{array}{c}\text { Whole Period } \\
(1990-91 \text { to } 2019-20)\end{array}$} \\
\hline & & Area & Production & Yield & Area & Production & Yield & Area & Production & Yield \\
\hline \multirow{2}{*}{ Groundnut } & CAGR & $0.01^{\mathrm{NS}}$ & $2.9^{\mathrm{NS}}$ & $2.9^{* * *}$ & $7.0^{*}$ & $10.3^{*}$ & $3.1^{*}$ & $3.60^{*}$ & $7.40^{*}$ & $3.60^{*}$ \\
\hline & $\mathrm{R}^{2}$ & 0.01 & 0.17 & 0.256 & 0.951 & 0.859 & 0.437 & 0.73 & 0.83 & 0.73 \\
\hline \multirow{2}{*}{ Soybean } & CAGR & $9.0^{*}$ & $9.1^{*}$ & $0.1^{*}$ & $3.1^{\mathrm{NS}}$ & $-0.2^{\mathrm{NS}}$ & $-3.2^{\mathrm{NS}}$ & $5.50^{*}$ & $5.30^{*}$ & $-0.20^{\mathrm{NS}}$ \\
\hline & $\mathrm{R}^{2}$ & 0.675 & 0.459 & 0.001 & 0.553 & 0.002 & 0.214 & 0.79 & 0.56 & 0.00 \\
\hline \multirow{2}{*}{$\begin{array}{l}\text { Rapeseed- } \\
\text { Mustard }\end{array}$} & CAGR & $-0.90^{\mathrm{NS}}$ & $1.6^{\mathrm{NS}}$ & $2.5^{*}$ & $-1.1^{\mathrm{NS}}$ & $1.3^{\mathrm{NS}}$ & $2.4^{*}$ & $0.70^{\mathrm{NS}}$ & $3.20^{*}$ & $2.40^{*}$ \\
\hline & $\mathrm{R}^{2}$ & 0.023 & 0.06 & 0.485 & 0.154 & 0.097 & 0.483 & 0.08 & 0.55 & 0.78 \\
\hline \multirow{2}{*}{ Sesame } & CAGR & $-5.6^{*}$ & $-5.3^{\mathrm{NS}}$ & $0.3^{\mathrm{NS}}$ & $-3.6^{* *}$ & $-1.6^{\mathrm{NS}}$ & $2.1^{\mathrm{NS}}$ & $-1.00^{\mathrm{NS}}$ & $2.00^{\mathrm{NS}}$ & $3.00^{*}$ \\
\hline & $\mathrm{R}^{2}$ & 0.443 & 0.076 & 0.001 & 0.292 & 0.042 & 0.093 & 0.06 & 0.06 & 0.22 \\
\hline \multirow{2}{*}{ Castor } & CAGR & $12.9^{*}$ & $13.7^{*}$ & $0.7^{\mathrm{NS}}$ & $2.8^{\mathrm{NS}}$ & $5.5^{* *}$ & $2.7^{* *}$ & $9.80^{*}$ & $12.10^{*}$ & $2.10^{*}$ \\
\hline & $\mathrm{R}^{2}$ & 0.58 & 0.54 & 0.006 & 0.171 & 0.27 & 0.277 & 0.78 & 0.80 & 0.25 \\
\hline \multirow{2}{*}{ Taramira } & CAGR & $1.00^{\mathrm{NS}}$ & $-2.8^{N S}$ & $-3.8^{*}$ & $0.4^{\mathrm{NS}}$ & $5.9^{\mathrm{NS}}$ & $5.6^{*}$ & $-1.40^{\mathrm{NS}}$ & $-1.20^{\mathrm{NS}}$ & $0.10^{\mathrm{NS}}$ \\
\hline & $\mathrm{R}^{2}$ & 0.003 & 0.023 & 0.357 & 0.001 & 0.043 & 0.744 & 0.01 & 0.01 & 0.00 \\
\hline Other & CAGR & $-20.6^{*}$ & $-17.7^{*}$ & $3.6^{*}$ & $10^{*}$ & $12^{*}$ & $1.8^{\mathrm{NS}}$ & $-9.30^{*}$ & $-3.30^{\mathrm{NS}}$ & $6.50^{*}$ \\
\hline Oilseeds & $\mathrm{R}^{2}$ & 0.833 & 0.79 & 0.345 & 0.224 & 0.156 & 0.004 & 0.44 & 0.07 & 0.29 \\
\hline
\end{tabular}

Note: "Significant @ 1\%, ${ }^{* *}$ Significant @ 5\% and NSNon-significant; Source: Authors own computation.

Table 3: Season-wise variability in area, production and yield of oilseed crops in Rajasthan

\begin{tabular}{|c|c|c|c|c|c|c|c|c|c|c|}
\hline \multirow{2}{*}{ Period } & \multirow{2}{*}{ Parameters } & \multicolumn{3}{|c|}{ Kharif Oilseeds } & \multicolumn{3}{|c|}{ Rabi Oilseeds } & \multicolumn{3}{|c|}{ Total Oilseeds } \\
\hline & & Area & Production & Yield & Area & Production & Yield & Area & Production & Yield \\
\hline Period-I & & 11.31 & 31.78 & 31.78 & 24.82 & 28.77 & 13.54 & 19.27 & 27.93 & 13.82 \\
\hline Period-II & $\begin{array}{l}\text { Instability } \\
\text { Index }(\%)\end{array}$ & 9.42 & 13.01 & 13.01 & 16.16 & 18.45 & 9.91 & 10.52 & 12.24 & 8.42 \\
\hline Whole Period & & 12.49 & 22.06 & 22.06 & 20.92 & 23.20 & 11.30 & 15.71 & 20.04 & 10.51 \\
\hline
\end{tabular}

Source: Authors own computation.

that acreage and output and yield of kharif, rabi and total oilseeds were found highly stabile with very low range of indices in period-II followed by period-I and whole period. The highest instability 31.78 per cent was reported in period-I for yield and output of kharif oilseeds crops followed by area and output of rabi oilseeds at 24.82 and 28.77 per cent respectively.

At state level, the variability in acreage, output and yield of groundnut soybean, rapeseed-mustard, sesame, caster and taramira were computed and showed in table 4. During period-I, the maximum instability of 72.97 per cent was found in production of taramira followed by sesame (65.36), castor (44.25), soybean (35.58), rapeseed-mustard (29.86) and groundnut (29.37). During same time, the highest instability of 91.23 per cent and 57.80 per cent per were also reported in area and yield of taramira and sesame, respectively. During period-II and whole study period, the maximum variability in area $(150.54 \%$ and $123.99 \%)$ and production (148.84\% and $125.33 \%)$ were also reported for taramira. However, the yield of selected oilseeds was slightly variable over the study period. Bairwa, et al. (2020) reported higher extent of variability in area and production of cumin in Jodhpur as compared to Rajasthan during 1991-92 to 2019-20.

Sources of output growth: The analysis of compound annual growth rate of acreage, yield and output of oilseeds present to general behaviour of growth and directions of changes in productivity and area. However, it does not explain to contribution of area and yield in changing output of respective crop(s). Therefore, decomposition analysis is obligatory to identify the share of factor(s) in changing output of agriculture and other products. To analyse the share of output growth in kharif and rabi oilseeds, the alteration in level of output is split up into yield, 
Table 4: Crop and period wise variability in area, production and yield of selected oilseed crops in Rajasthan

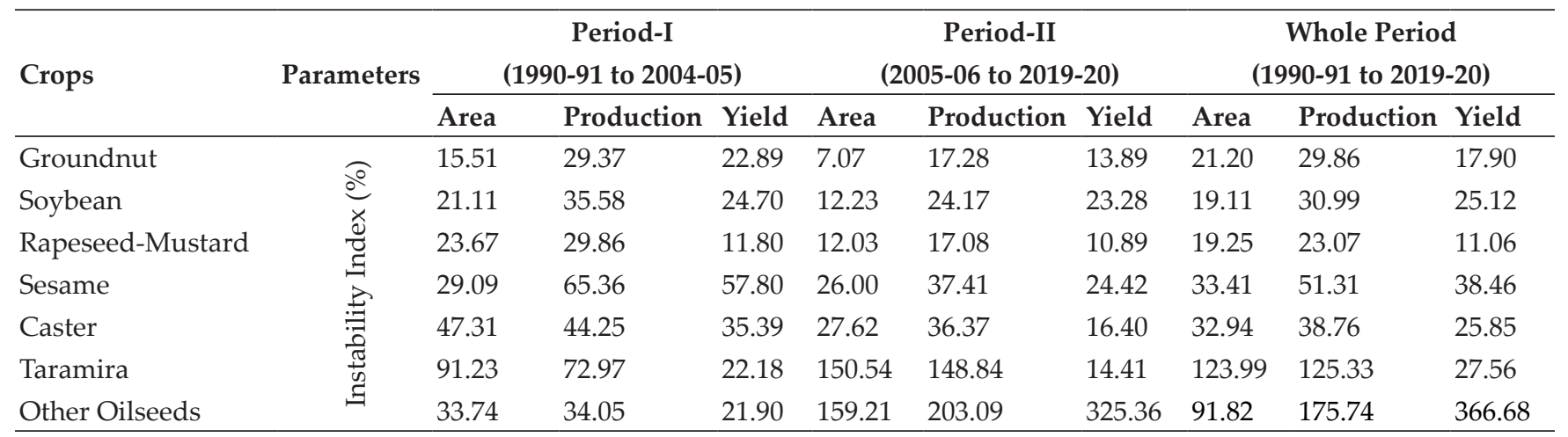

Source: Authors own computation.

Table 5: Season wise sources of output growth in major oilseed crops in Rajasthan

\begin{tabular}{llllllllll}
\hline & \multicolumn{3}{c}{ Kharif Oilseeds } & \multicolumn{2}{c}{ Rabi Oilseeds } & \multicolumn{2}{c}{ Total Oilseeds } \\
\cline { 2 - 10 } Period & Yield & Area & \multicolumn{2}{l}{ Interaction } & Yield & Area & Interaction & Yield & \multicolumn{2}{c}{$\begin{array}{c}\text { Area } \\
\text { Effect }\end{array}$} & $\begin{array}{l}\text { Interaction } \\
\text { Effect }\end{array}$ \\
\hline Period-I & 48.85 & 18.17 & 32.98 & 16.95 & 89.70 & -6.65 & 20.53 & 67.32 & 12.15 \\
Period-II & 49.82 & 51.86 & -1.68 & 27.32 & 81.11 & -8.43 & 37.99 & 76.62 & -14.61 \\
Whole Period & 46.38 & 43.96 & 9.66 & 31.06 & 74.91 & -5.97 & 28.46 & 67.7 & 3.84 \\
\hline
\end{tabular}

Source: Authors own computation.

Table 6: Contribution of Area and yield in alteration of production of major oilseed crops in Rajasthan

\begin{tabular}{|c|c|c|c|c|c|c|c|c|c|}
\hline \multirow{2}{*}{ Crops } & \multicolumn{3}{|c|}{$\begin{array}{c}\text { Period-I } \\
(1990-91 \text { to 2004-05) } \\
\end{array}$} & \multicolumn{3}{|c|}{$\begin{array}{c}\text { Period-II } \\
(2005-06 \text { to 2019-20) }\end{array}$} & \multicolumn{3}{|c|}{$\begin{array}{c}\text { Whole Period } \\
(1990-91 \text { to 2019-20) }\end{array}$} \\
\hline & $\begin{array}{l}\text { Yield } \\
\text { Effect }\end{array}$ & $\begin{array}{l}\text { Area } \\
\text { Effect }\end{array}$ & $\begin{array}{l}\text { Interaction } \\
\text { Effect }\end{array}$ & $\begin{array}{l}\text { Yield } \\
\text { Effect }\end{array}$ & $\begin{array}{l}\text { Area } \\
\text { Effect }\end{array}$ & $\begin{array}{l}\text { Interaction } \\
\text { Effect }\end{array}$ & $\begin{array}{l}\text { Yield } \\
\text { Effect }\end{array}$ & $\begin{array}{l}\text { Area } \\
\text { Effect }\end{array}$ & $\begin{array}{l}\text { Interaction } \\
\text { Effect }\end{array}$ \\
\hline Groundnut & 49.54 & 56.64 & -6.18 & 24.7 & 70.65 & 4.65 & 27.91 & 69.39 & 2.70 \\
\hline Soybean & 12.96 & 73.34 & 13.7 & 179.31 & -224.06 & 144.75 & -183.99 & 397.44 & -113.45 \\
\hline $\begin{array}{l}\text { Rapeseed- } \\
\text { Mustard }\end{array}$ & 15.3 & 78.33 & 6.37 & -614.06 & 1256.9 & -542.8 & 39.42 & 37.56 & 23.02 \\
\hline Sesame & 211.1 & 20.25 & -131.4 & 304.19 & 23.54 & -227.7 & 80.94 & 9.76 & 9.30 \\
\hline Caster & -101.33 & 4.19 & 197.14 & 61.88 & 0.31 & 37.81 & 36.97 & 79.94 & -16.91 \\
\hline Taramira & -85.59 & 416.85 & -231.3 & 7.81 & 95.78 & -3.59 & -0.76 & 131.21 & -30.45 \\
\hline Other Oilseeds & -24.55 & 114.77 & 9.78 & 365.26 & 2919.5 & -3185 & -100.09 & -482.19 & 682.28 \\
\hline
\end{tabular}

Source: Authors own computation.

area and interaction effects. The seasonal change in oilseeds production is presented in table 5 . It was revealed from the table that during period-I, the yield effect (48.85) and area effect (89.70) in more dominant in kharif and rabi season oilseeds respectively. During period-II, the productions of kharif oilseeds were equally contributed by area and yield effect. In case of rabi oilseeds production, the maximum part is contributed by area effect (81.11). The principle component analysis of selected oilseed crops is reported in table 6 . The results presented in table showed that during period-I, the area effect (416.85) and yield effects (211.10) were highly dominant in production of taramira and sesame crops, respectively. At the same time, the production of castor was boosted up due to interaction effect (197.14) contribution. During period-II, the maximum contribution in output alteration was reported 1256.9 and 304.19 per cent in rapeseed-mustard and sesame respectively. During overall study period, the area effect (397.44) and yield effect (80.94) were more effective in 
production of soybean and sesame respectively. The contribution of area was dominant in growth of soybean, taramira, castor and groundnut during overall study period. During overall selected study period; yield effect was contributed dominantly in growth of chickpea, pigeonpea, green gram and lentil while area effect was more effective in growth of black gram. Bairwa, et al. (2020) depicted in their study that growth in output of kharif and rabi pulses was principally contributed by yield effect and area effect, respectively.

\section{CONCLUSION}

Oilseeds are playing a vital role in national food and nutritional security. The expanded rate in the area of total oilseeds in Rajasthan was reported to be always been positive over the study period. At the same time, there was significant growth rate in output than the growth rate in acreage due to better performance reported by the yield. On the seasonal pattern, a more coverage in oilseeds production has been found in kharif seasona than rabi. The production of castor, groundnut, and soybean were contributed distinct share in total oilseed production of the state. The income level of oilseeds growing farmers can be increased by the productivity improvement through varieties and technological breakthrough. Thus, the improved productivity can fetch higher revenue to the farmers and may cancel out the benefits of other crops than oilseeds. Further, a forward step in the production performance of major oilseed crops can also helpful to identify the hidden potential of farmers for these crops. During the whole study period, yield of selected oilseed crops is highly stable than other oilseed crops. the output level of soybean is completely changed due to expanded in the area. The principle component analysis suggested that during period -I and II area effect was played major role in changing production of taramira and rapeseed-mustard.

\section{ACKNOWLEDGEMENTS}

The authors are thankful to the Agriculture University, Jodhpur, Rajasthan for its pecuniary and ethical support to conduct this research study. Moreover, the authors are also indebted to other persons who were directly and indirectly supported for their positive suggestions that helped to improve the content of this study.

\section{REFERENCES}

Agarwal, P.K., Singh, O.P. Verma, D.K. Shushila, K. and Sen, C. 2011. Growth and instability of pulses in India. The Allahabad Farmer, LVVII(1): 41-53.

Angles, S. 2001. Production and export of turmeric in South India-An economic analysis. M.Sc. Agricultural Economics thesis, (Unpublished) University of Agricultural Sciences Dharwad.

Anonymous 2017-18. Directorate of Economics and Statistics, Department of Agriculture and Cooperation, Government of India.

Bairwa, K.C., Balai, H.K., Meena, G.L., Meena, Prasad, D. Kumari, Y., Singh, H. and Yadav, A. 2020. Inter-temporal production performance of pulse crops: In Indian context. Eco. Affa., 65(3): 01-08.

Bairwa, K.C., Meena, G.L., Meena, P.C., Burark, S.S., Singh, H., Upadhyay, B. and Chaplot, P.C. 2020. Sources of output growth and variability in production of cumin in Jodhpur vis-à-vis Rajasthan. Eco. Affa., 65(4): 543-549.

Basitine, C.L. and Palanisami, K.P. 1994. An analysis of growth trends in principal crops in Kerala. Agril. Situation in India, 48 (12): 885-891.

DES, 2019. State Domestic Product of Rajasthan-2018-19 report. Directorate of Economics \& Statistics (DES), Jaipur Rajasthan.

DES, 2020. Agricultural Statistics of Rajasthan-2017-18 report. Directorate of Economics \& Statistics (DES), JaipurRajasthan.

Joshi, P.K. and Saxena, R. 2002. A profile of pulses production in India: Facts, trends and opportunities. Indian Journal of Agril. Eco., 57(3): 326-339.

Kalmkar, S.S., N.V. Shende and Atkare, V.G. 2002. Course cereals and pulses production in India: Trends and decomposition analysis. Agril Situation in India, 59(1): 581-587.

Kumar, N.S.P., Radha, Y., Rao, D.V.S., Rao, V.S. and Gopikrishna, T. 2018. Growth and Instability of pulses production in Andhra Pradesh. Int. Res. J. Curr. Micro. Appl. Sci., 7(11): 490-494.

Minhas, B.S. and Vaidyanathan, A. 1965. Growth of crop output in India 1951-54 to 1958-61: An analysis by component elements. J. Indian Soc. Agri.l Statis., 17(2): 230-252.

Nimbrayan, P.K., Sunita, Bhatia, J.K. and Heena. 2019. Growth and instability inarea, production and productivity of Barley in Haryana vis-à-vis India. Curr. J. Appl. Sci.Tech., 35(6): 1-8.

Reddy, V.K. and Immanuelraj, K. 2017. Area, production, yield trends and pattern of oilseeds growth in India. Eco. Affa., 62(2): 327-334.

Sharma, K.L. 1977. Measurement of the effects to area, yield and prices in the increase of value of crop output in India. Agril. Situation in India, 32(1-9): 348-350.

Srivastav, S.K. Sivaramane, N. and Mathur, V.C. 2010. Diagnosis of pulses performance of India. Agril. Eco. Res. Rev., 23(4): 137-148. 
